\title{
KAJIAN KESIAPAN LABORATORIUM PUSAT TEKNOLOGI SATELIT LAPAN SEBAGAI LABORATORIUM PENGUJIAN TERHADAP PRODUK SATELIT KUBUS (CUBESAT) SESUAI DENGAN ISO 17025:2017
}

\section{Review On LAPAN Satellite Technology Center Laboratory As Testing Laboratory For Cubes Satellite Products According To ISO 17025: 2017}

\author{
Hogan Eighfansyah Susilo dan Iqbal Vernando² \\ 1,2Lembaga Penerbangan dan Antariksa Nasional \\ Jalan Pemuda Pemuda Persil No.1, Rawamangun, Jakarta Timur \\ E-mail: hogan.eighfansyah@lapan.go.id
}

\begin{abstract}
Abstrak
Satelit kubus adalah satelit berukuran kecil yang termasuk dalam kelas nano dengan ukuran $10 \mathrm{~cm} \times 10 \mathrm{~cm} \times 10$ $\mathrm{cm}$. Satelit tipe ini berkembang pesat dikarenakan harga lebih terjangkau, ringan, mudah untuk didesain dan diluncurkan bahkan dapat menggantikan fungsi satelit yang lebih besar yang telah ada. Perkembangan dan pemanfaatan diberbagai bidang membuat banyak perusahaan maupun negara meluncurkan satelit ini. Hal ini dapat mengakibatkan potensi gangguan keamanan dan keselamatan jika tidak adanya aturan maupun standar tentang penjaminan mutu terkait produk satelit ini. Pada tahun 2019 ditetapkan Standar Nasional Indonesia (SNI) terkait satelit kubus (Cubesat) yang merupakan adopsi dari ISO 17770:2017 dengan beberapa modifikasi sebagai jawaban kebutuhan standar satelit tersebut. Namun terdapat kendala dalam penerapannya dikerenakan belum ada lembaga penilaian kesesuaian (LPK) yang sesuai dengan standar tersebut. LAPAN yang bertugas sebagai mengawasi setiap penyelengaraan keantrikasaan dan memiliki fasilitas laboratorium khusus satelit dapat menjadi LPK. Untuk mewujudkannya perlu adanya laboratorium pengujian yang terakreditasi ISO 17025:2017. Kesiapan laboratorium LAPAN untuk pengujian sebagai pengembangan LPK di bidang penerbangan dan antariksa khususnya untuk produk satelit kubus perlu dikaji. Dari hasil analisis kesenjangan dihasilkan bahwa laboratorium pusat teknologi satelit memiliki kesiapan sebesar 18\% dari semua persyaratan ISO 17025:2017. Selain itu dari hasil analisis persyaratan teknis pada regulasi terkait satelit kubus secara instrument dan personel sudah dapat dilakukan. Namun perlu adanya penetapan regulasi yang efektif dalam pengembangan dan penerapan standar yang ada.
\end{abstract}

Kata kunci: analisis kesenjangan, LAPAN, satelit kubus(cubesat), laboratorium pengujian, ISO 17025:2017

\section{Abstract}

Cube satellites are small satellites belonging to the nano class with a size of $10 \mathrm{~cm} \times 10 \mathrm{~cm} \times 10 \mathrm{~cm}$. This type of satellite is growing rapidly because it is more affordable, lightweight, easy to design and launch, and can even replace the functions of existing larger satellites. The development and utilization in various fields have prompted many companies and countries to launch this satellite. This can lead to potential security and safety problems if there are no rules or standards regarding quality assurance related to this satellite product. In 2019 the Indonesian National Standard (SNI) was determined regarding the cube satellite (Cubesat) which was an adoption of ISO 17770:2017 with several modifications in response to the needs of the satellite standard. However, there are obstacles in its application because there is no conformity assessment agency (LPK) that complies with these standards. LAPAN, which has the task of supervising every engineering activity and having a special satellite laboratory facility, can become a conformity assessment agency. To become that, it is necessary to have a testing laboratory accredited with ISO 17025. The readiness of the LAPAN laboratory for testing as a conformity assessment agency in the field of aviation and space, especially for cube satellite products, needs to be studied. From the results of the gap analysis, it was found that the satellite technology center laboratory has a readiness of $18 \%$ of all the requirements of ISO 17025. Apart from that, the results of the analysis of technical requirements on regulations related to the cube satellite instrumentally and personnel can be done. However, it is necessary to establish effective regulations in the development and application of existing standards.

Keyword: gap analysis, LAPAN, Cubesat, testing laboratory, ISO 17025:2017

\section{PENDAHULUAN}

Sepanjang tahun 2019, Komite Teknis SNI 49-01 bersama tim perumus dari Pusat Teknologi Satelit LAPAN telah melakukan perumusan Standar
Nasional Indonsia (SNI) dibidang teknologi penerbangan dan antariksa yang menghasilkan SNI satelit kubus (cubesat). Standar satelit kubus ini merupakan standar yang diadopsi dari standar ISO 17770:2017 dan dimodifikasi sesuai dengan kebutuhan dan teknologi yang sedang 
berkembang. Satelit kubus merupakan satelit kelas nano dengan ukuran paling kecil sebesar 10 $\mathrm{cm} \times 10 \mathrm{~cm} \times 10 \mathrm{~cm}$. Satelit kubus memiliki keunggulan yaitu lebih terjangkau, ringan dan jauh lebih mudah untuk didesain dan diluncurkan. Perkembangan dan pemanfaatan teknologi satelit diberbagai bidang akan mengakibatkan banyak satelit serupa yang diluncurkan ke orbit bumi. Jika tidak adanya standar sebagai penjaminan mutu terkait produk ini dapat mengakibatkan potensi gangguan keamanan dan keselamatan, seperti satelit gagal orbit bertabrakan dengan satelit lain, satelit jatuh kembali ke bumi mengenai pemukiman dan satelit meledak yang diakibatkan dari mutu dari produk satelit kubus yang tidak sesuai standar. Terkait dengan hal tersebut, penilaian kesesuaian produk satelit kubus sangat penting dalam penetapan standar tersebut. Hal ini berkaitan dengan penjaminan mutu dan kemanan serta keselamatan dari produk satelit kubus itu sendiri.

LAPAN sebagai lembaga pemerintah yang berwenang dalam bidang keantarikaan di Indonesia diamanati untuk mengawasi kepatuhan pemenuhan standar dan prosedur keamanan dan keselamatan yang dilaksanakan oleh setiap penyelenggaraan keantariksaan di Indonesia sesuai Undang-Undang Nomor 21 tahun 2013 tentang Keantariksaan. Namun demikian, LAPAN belum memiliki lembaga penilai kesesuaian untuk menilai mutu produk yang sesuai dengan standar tersebut. Salah satu instumen yang mengukur kualitas, mutu dan keamanan produk untuk keberterimaan oleh lembaga penilai kesesuaian adalah laboratorium uji yang terakreditasi. Laboratorium uji tersebut harus terakreditasi sesuai dengan standar ISO/IEC 17025:2017 General Requirements for the Competence of Requirements for the Competence of Testing and Calibration Laboratories. Maka dari itu, LAPAN perlu mempersiapkan terhadap fasilitas laboratoriumnya untuk dapat menjadi lembaga penilai kesesuaian untuk menilai mutu produk sebagai tanggungjawab pengawasan kepatuhan standar satelit kubus ini.

Dengan latarbelakang tersebut, perlu adanya kajian terhadap kesiapan laboratorium LAPAN untuk pengujian sebagai pengembangan LPK di bidang penerbangan dan antariksa khususnya untuk produk satelit kubus. Hasil identifikasi kesiapan ini diharapkan dapat menjadi rekomendasi dalam pengembangan LPK yang dibutuhkan dalam implementasi standar satelit kubus (cubesat) ini.

\section{TINJAUAN PUSTAKA}

\subsection{Penilaian kesesuaian}

Penilaian kesesuaian menurut SNI/ISO 17000:2009 merupakan kegiatan yang mencakup pengujian, inspeksi , sertifikasi serta akreditasi. Proses penilaian kesesuaian bertujun untuk membuktikan bahwa produk, proses, jasa, personel, sistem serta lembaga sesuain dengan persyaratan standar yang ada. Lembaga yang melakukan kegiatan penilaian kesesuaian disebut lembaga penilaian kesesuaian (LPK).

Salah satu penilaian kesesuian adalah dengan cara pengujian. Pengujian menurut SNI/ISO 17000:2009 didefiniksan sebagai penentuan karakteristik objek uji berdasar prosedur yang telah ditentukan, atau bisa dikatakan satu cara untuk menentukan kadungan atau parameter yang dapat menentukan mutu produk, bahan, komponen dan lain sebagainya.

Sertifikasi merupakan proses pengesahan dari lembaga penilaian kesesuaian (LPK) yang berkaitan dengan objek penilaian kesesuaian seperti produk, sistem, proses atau personel. Untuk sertifkasi produk, bertujuan memberikan pengakuan bahwa produk, sistem, proses atau personel telah sesuai dengan persyaratan yang telah ditetapkan pada standar. Sertifkasi produk tersendiri dilakukan oleh Lembaga Sertifikasi Produk (LSPro) (BSN,2018).

\subsection{ISO/IEC 17025: 2017}

Standar ISO/IEC 17025:2017 merupakan standar tentang akreditasi laboratorium yang menjamin hasil pengukuran dan kalibrasi memiliki tingkat kepercayaan yang tinggi (Anastopoulus, 2017). Pada standar diatur beberapa persyaratan yaitu: (KAN, 2017)

a. Persyaratan umum yang terdiri dari manajemen ketidakberpihakan dan kerahasiaan.

b. Persyaratan struktural yang terdiri dari struktur organisasi dan manajemen puncak serta mekanisme untuk menjaga ketidakberpihakan.

c. Persyaratan sumberdaya yang terdiri dari pengelolaan personil, fasilitas serta ketelusuran metrologi.

d. Persyaratan proses yang terdiri dari kaji ulang permintaan, validasi metode uji, pengambilan sampel, kalibrasi, ketidakpastian pengukuran, rekaman teknis, ketidakpastian ukuran, pelaporan hasil serta penanganan keluhan.

e. Persyaratan manajemen yang terdiri dari dokumentasi sistem manajemen umum, pengendalian dokumen, pengendalian 
rekaman, tinjauan manajemen, audit internal, tindakan korektif serta tindakan pencegahan.

\subsection{Analsis Kesenjangan (Gap Analysis)}

Analisis kesenjangan (Gap analysis) menerupakan metode dengan membandingkan kondisi yang ada dengan kondisi yang akan dicapai. Dengan analisis kesenjangan dapat mengidentifikasi kebutuhan yang bisa mengurangi kesenjangan yang ada (Brocks,2010). Untuk melaksanakan analisis kesenjangan diperlukan tujuan yang jelas yang ingin diperoleh. Dalam pengambilan data pastikan bahwa informasi yang dikumpulkan berasal dari sumber yang tepat dan analisis kondisi yang ada. Langkah terakhir adalah mengidentifikasi bagaimana kita dapat menjembatani kesenjangan yang terjadi diantara kondisi saat ini dan target kita dimasa yang akan datang.

Di dalam proses penerapan ISO dan atau SNI, analisis kesenjangan merupakan langkah awal. (Admaja, 2013) Dengan adanya analisis kesenjangan diharapkan dapat diketahui langkahlangkah apa yang perlu diambil agar dengan mudah dapat mencapai kondisi atau standard yang diharapkan, dalam hal ini sesuai dengan standard yang ditentukan di dalam ISO dan atau SNI yang dijadikan acuan.

\section{METODE PENELITIAN}

\subsection{Identifikasi regulasi terkait satelit kubus}

Metode yang digunakan pada penelitian ini dengan studi literatur yaitu mengidentifikasi regulasi terkait satelit kubus yang berlaku secara nasional maupun internasional. Identifikasi ini mencari parameter mutu yang akan menjadi acuan kondisi laboratorium pengujian ideal sehingga dapat memberikan rekomendasi perbaikan agar sesuai dengan regulasi yang berlaku.

\subsection{Analisis kesenjangan pemenuhan persyaratan ISO/IEC 17025: 2017}

Analisis ini dilakukan dengan melakukan kunjungan ke laboratorium dan melakukan wawancara kepada perwakilan laboratorium. Wawancara ini dilakukan bersama dengan asesor dari TUV Reinland yang telah berpengalaman dalam akreditasi laboratorium sesuai ISO/IEC 17025:2017. Kondisi dan kemampuan laboratorium akan digunakan untuk menganalisis kesenjangan persyaratan ISO/IEC 17025:2017 berdasarkan wawancara serta observasi di lapangan. Observasi ini dilakukan ke laboratorium
Pusat Teknologi Satelit (Pusteksat) LAPAN pada 29 Mei 2019.

Penilaian kesiapan dengan menggunakan indeks kesiapan. Indeks kesiapan diperoleh dari penilaian asesor terhadap kondisi yang ada saat ini, dengan item penilaian mengacu pada klausul ISO/IEC 17025. Tingkat kesiapan dinilai dengan menggunakan skala likert $(0,1,2,3,4)$ yang mewakili : Tidak Memadai - Kurang Memadai Cukup Memadai - Memadai - Sangat Memadai.

Tabel 1 Skala Likert Tingkat Kesiapan

\begin{tabular}{lll}
\hline Nilai & Status & Keterangan \\
\hline 0 & Tidak memadai & $\begin{array}{l}\text { Jika persyaratan belum } \\
\text { dilakukan sama sekali } \\
\text { Jika persyaratan mulai } \\
\text { dilakukan }\end{array}$ \\
2 & $\begin{array}{l}\text { Kurang } \\
\text { memadai }\end{array}$ & $\begin{array}{l}\text { Persyaratan mulai dilakukan } \\
\text { dan diterapkan }\end{array}$ \\
3 & memadai & $\begin{array}{l}\text { Persyaratan sudah dilakukan } \\
\text { dan diterapkan } \\
\text { Memadai }\end{array}$ \\
4 & Sangat & $\begin{array}{l}\text { Persyaratan sudah dilakukan } \\
\text { dan diterapkan dan terdapat } \\
\text { dokumnetasi resmi }\end{array}$ \\
\hline
\end{tabular}

Poin skala Likert tiap item dijumlah dan dibagi dengan poin maksimal. Hasil perhitungan inilah yang menjadi indeks kesiapan.

Pada analisis ini akan dibagi beberapa kategori sesuai dengan klausul pada ISO/IEC 17025:2017:

a. Klausul 4 Persyaratan Umum;

b. Klausul 5 Persyaratan Struktur;

c. Klausul 6 Persyaratan Sumber Daya;

d. Klausul 7 Persyaratan Proses;

e. Klausul 8 Persyaratan Sistem Manajemen

\section{HASIL DAN PEMBAHASAN}

\subsection{Regulasi terkait satelit kubus}

Satelit kubus atau lebih dikenal cubesat merupakan satelit berukuran kecil dengan ukuran paling kecil sebesar $10 \mathrm{~cm}$ x $10 \mathrm{~cm}$ x $10 \mathrm{~cm}$ (ISO,2017). satelit ini masuk dalam satelit tipe nano. Regulasi satelit kubus hampir sama dengan regulasi dengan satelit dengan ukuran yang besar namun perbedaan bergantung dengan aktivitas yang akan dilakukan oleh satelit tersebut. Terdapat beberapa regulasi terkait dengan satelit yang ada di beberapa negara seperti Amerika serikat, Eropa dan Asia. Secara umum untuk regulasi satelit kubus mengatur beberapa aspek yaitu ijin frekuensi radio, registrasi pemakaian orbit, lisensi satelit dan regulasi mitigasi sampah antariksa (Jakhu, nd). 
Berdasar hukum internasional dari hasil kesepakatan PBB setiap benda yang diluncurkan ke antariksa harus teregistrasi milki entitas publik, negara ataupun perusahaan dalam satu negara dan didaftar ke sekretaris PBB (PBB,1967). Tujuan ini untuk dapat mengidentifikasi satelit tersebut dan jika terjadi sebuah kecelakaan maka kewajiban dan pertanggung jawabannya jelas.

Semua jenis satelit menggunakan frekuensi radio untuk menerima maupun mengirimkan data sebagaimana satelit difungsikan. Penggunaan Frekuensi radio pada satelit diperlukan ijin. Hal ini untuk menghindari adanya interferensi. penggunaan frekuensi radio diberlakukan untuk semua jenis. Regulasi tentang penggunaan frekuensi sangat ketat di tingkat nasional maupun internasional. Frekuensi radio merupakan sumber yang terbatas dan digunakan oleh seluruh negara dan tidak memandang batas negara. Secara intenasional penggunaan frekuensi ini diatur oleh International Telecommunication Union (ITU) (ITU,2016). Untuk jenis nano dan pico satelit menggunakan spektrum frekuensi radio yang dialokasikan untuk layanan amatir satelit dan MetSat dengan rentang frekuensi $30-3000 \mathrm{MHz}$. Satelit tersebut harus mengikuti peraturan regulasi radio untuk koordinasi dan pengenalan satelit untuk mengetahui misi dari satelit tersebut sesuai standar ISO 17770:2017.

Lisensi satelit setiap negara berbeda-beda. Secara umum lisensi satelit ini lebih mengatur aktifitas misi yang dapat dilakukan oleh satelit tersebut bukan dilihat dari ukuran dan besar satelit. Jika sebuah negara belum menerapkan sistem lisensi maka satelit tersebut harus mengikuti aturan hukum internasional (PBB,2007).

Seiring banyak satelit kecil yang diluncurkan di antariksa membuat banyak objek satelit yang menjadi sampah antariksa di orbit rendah bumi. Satelit kecil secara umum memiliki umur yang pendek dan secara sejarah satelit nano memiliki tingkat kegagalan sebesar 52\% (Domain, n.d). Maka terdapat standar teknis maupun panduan yang berlaku internasional maupun nasional diberapa negara. Aturan tersebut berdasarkan standar internasional mitigasi sampah antariksa (ISO,2011) yaitu:

a. Membatasi puing yang lepas saat beroperasi normal.

b. Meminimalkan potensi pecahaan saat fase operasi

c. Membatasi kemungkinan tabrakan orbit

d. Dilarang melakukan aktivitas berbahaya

e. Meminimalkan potensi ledakan akibat penyimpan daya saat misi f. Untuk objek satelit yang berada pada orbit rendah bumi setelah misinya berakhir harus pindah ke area orbit yang disediakan maksimal 25 tahun dan setelah itu harus dapat kembali dengan aman ke bumi.

g. Sedangakan untuk di orbit geostasioner bumi maka satelit harus pindah di area orbit yang disediakan selama 100 tahun.

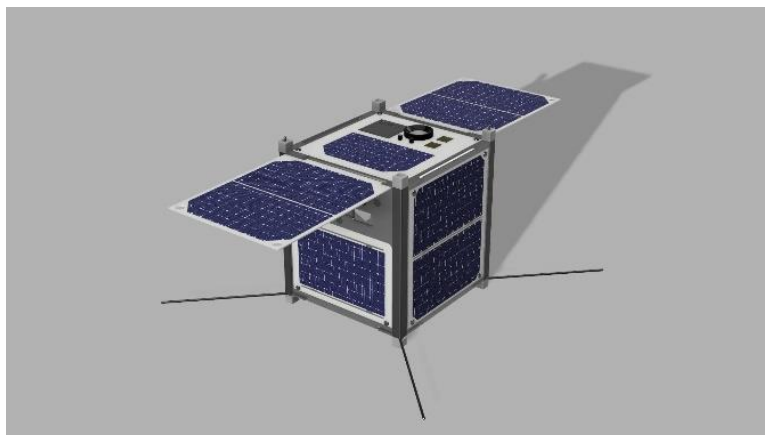

Gambar 1 Satelit kubus $1 \mathrm{U}$.

Untuk dapat memverifikasi satelit kubus yang dibuat apakah sesui dengan aturan dan persyaratan maka perlu adanya pengujian sebelum diluncurkan. Sesuai dengan standar ISO 17770:2017 tentang satelit kubus yang juga sebegai acuan dari SNI satelit kubus maka terdapat beberapa yaitu:

a. Uji Berat

b. Uji Interferensi elektromagnetik

c. Uji Getaran acak

d. Uji Termal vakum

e. Uji Kejut

f. Inpeksi visual

Masing masing uji ini memiliki parameter yang berbeda beda bergantung dengan wahana yang akan meluncurkannya (Planet System Corporation, 2018).

Uji ini sudah dapat dilakukan di indonesia tepatnya di laboratorium milik Pusat Teknologi Satelit LAPAN. Laboratorium ini juga telah mengji beberapa satelit yang dibuat oleh LAPAN.

Regulasi tentang satelit ataupun satelit kubus tersendiri di Indonesia masih belum diterapkan. Padahal produk satelit yang dikembangkan di dalam negeri sudah cukup banyak. Dengan adanya standar tentang satelit kubus ini dapat menjadi pedoman perkembangan produk satelit yang terjamin mutu. 
Kajian Kesiapan Laboratorium Pusat Teknologi Satelit LAPAN sebagai Laboratorium Pengujian terhadap Produk Satelit Kubus (Cubeset) sesuai Dengan ISO 17025:2017 Hogan Eighfansyah Susilo dan Iqbal Vernando

4.2 Kondisi Aktual Laboratorium dalam Pemenuhan Persyaratan ISO/IEC 17025:2017 dan Rekomendasi Pemenuhan Persyaratan atas Kesenjangan yang Ditemukan

Analisa dan pembahasan merupakan hasil dari penilaian terhadap pemenuhan persyaratan ISO/IEC 17025: 2017. Penilaian ini berdasarkan oleh expert judgment dari asesor TUV Reinland dengan menggunakan skala likert. Dari hasil penilaian terdapat dua kategori penilaian yaitu tingkat kesiapan dan kesenjangan antara kondisi yang sesuai dengan standar dengan kondisi saat ini.

\section{Persyaratan umum}

Persyaratan umum berisi persyaratan yang diperlukan sebagai laboratorium pengujian, dengan hasil penilaian sebagai berikut:

Tabel 2 Tingkat Kesiapan Persyaratan Umum

\begin{tabular}{lcc}
\hline \multicolumn{1}{c}{ Klausul 4 } & \multicolumn{2}{c}{ ISO/IEC 17025:2017 } \\
\cline { 2 - 3 } $\begin{array}{c}\text { Persyaratan } \\
\text { umum }\end{array}$ & $\begin{array}{c}\text { Tingkat } \\
\text { Kesiapan }\end{array}$ & GAP \\
Ketidak- & $0 \%$ & 1 \\
berpihakan & $0 \%$ & 1 \\
Kerahasian & $0 \%$ & 1 \\
Rata-rata & $0 \%$ & \\
\hline
\end{tabular}

Dari hasil penilaian didapatkan untuk persyaratan umum masih memiliki tingkat kesiapan sangat rendah. Rendahnya skor ini karena laboratorium belum memilik kebijakan mengenai ketidakberpihakan dan kerahasiaan. Dalam persyaratan umum, Ketidakberpihakan dan kerahasiaan sangat penting untuk laboratorium pengujian. Hasil dari pengujian haruslah tidak memihak dan sebenar-benarnya sesuai hasil uji. Laboratorium juga harus menjaga hasil ujinya dan hanya diberitahukan kepada pemohon.

\section{Persyaratan struktur}

Persyaratan struktur merupakan persyaratan mengenai struktur organisasi dan manajemen yang ada pada laboratorium pengujian.

Tabel 3. Tingkat Kesiapan Persyaratan Struktur

\begin{tabular}{ccc}
\hline Klausul 5 & \multicolumn{2}{c}{ ISO/IEC } \\
\cline { 2 - 2 } $\begin{array}{c}\text { Persyaratan } \\
\text { struktur }\end{array}$ & $\begin{array}{c}\text { Tingkat } \\
\text { Kesiapan }\end{array}$ & GAP \\
\hline
\end{tabular}

Legalitas

$\begin{array}{lll}\text { Hukum } & 50 \% & 0,5\end{array}$

Laboratorium

\begin{tabular}{|c|c|c|}
\hline \multirow{2}{*}{$\begin{array}{c}\text { Klausul } 5 \\
\text { Persyaratan } \\
\text { struktur }\end{array}$} & \multicolumn{2}{|c|}{ ISO/IEC 17025:2017 } \\
\hline & $\begin{array}{l}\text { Tingkat } \\
\text { Kesiapan }\end{array}$ & GAP \\
\hline $\begin{array}{l}\text { Manajemen } \\
\text { Laboratorium }\end{array}$ & $0 \%$ & 1 \\
\hline $\begin{array}{l}\text { Ruang } \\
\text { Lingkup } \\
\text { Kegiatan }\end{array}$ & $75 \%$ & 0,25 \\
\hline $\begin{array}{l}\text { Struktur } \\
\text { organisasi }\end{array}$ & $37,5 \%$ & 0,625 \\
\hline $\begin{array}{l}\text { Tanggung } \\
\text { Jawab } \\
\text { Pengelolaan } \\
\text { Sistem } \\
\text { Manajemen }\end{array}$ & $25 \%$ & 0,75 \\
\hline $\begin{array}{l}\text { Efektifitas dan } \\
\text { Integritas } \\
\text { Sistem } \\
\text { Manajemen }\end{array}$ & $0 \%$ & 1 \\
\hline Rata-rata & $31,25 \%$ & 0,6875 \\
\hline
\end{tabular}

Dalam persyaratan struktur pada laboratorium pusat teknologi satelit LAPAN secara garis besar masih besar gap terhadap persyaratan ISO. Gap ini diakibatkan karena laboratorium belum ada manajemen pertanggung jawaban atas kegiatan pengujian dan sistem manajemen yang sesuai dengan persyaratan ISO/IEC 17025:2017.

Persyaratan ISO yang paling siap yang telah dipenuhi adalah persyaratan untuk ruang lingkup dan legalitas hukum. Hal ini dikarenakan laboratroium ini sacara legalitas telah ada secara hukum dan merupakan bagian dari satuan kerja dari LAPAN. Untuk ruang lingkup kegiatan pengujian telah secara rutin dilakukan pada fasilitas yang permanen pada laboratorium.

\section{Persyaratan sumber daya}

Persyaratan sumber daya merupakn persyaratan terkait sumber daya manusia yang diperlukan dalam proses berjalannya laboratorium pengujian/kalibrasi. Dari hasil penilaian didapatkan hasil sebagai berikut:

Tabel 4. Tingkat Kesiapan Persyaratan Sumberdaya

\begin{tabular}{|c|c|c|}
\hline \multirow{2}{*}{$\begin{array}{c}\text { Klausul } 6 \\
\text { Persyaratan } \\
\text { Sumber daya }\end{array}$} & \multicolumn{2}{|c|}{ ISO/IEC 17025:2017 } \\
\hline & $\begin{array}{c}\text { Tingkat } \\
\text { Kesiapan }\end{array}$ & GAP \\
\hline Personil & $25 \%$ & 0,75 \\
\hline $\begin{array}{l}\text { Fasilitas dan } \\
\text { Kondisi } \\
\text { Lingkungan }\end{array}$ & $35 \%$ & 0,65 \\
\hline Peralatan & $37,5 \%$ & 0,625 \\
\hline
\end{tabular}




\begin{tabular}{lcc}
\hline \multicolumn{1}{c}{ Klausul 6 } & \multicolumn{2}{c}{ ISO/IEC 17025:2017 } \\
\cline { 2 - 2 } $\begin{array}{c}\text { Persyaratan } \\
\text { Sumber daya }\end{array}$ & $\begin{array}{c}\text { Tingkat } \\
\text { Kesiapan }\end{array}$ & GAP \\
\hline $\begin{array}{l}\text { Ketertelusuran } \\
\text { metrologi }\end{array}$ & $0 \%$ & 1 \\
$\begin{array}{l}\text { Produk dan } \\
\text { Jasa dari }\end{array}$ & $0 \%$ & \\
$\begin{array}{l}\text { Penyedia } \\
\text { Eksternal }\end{array}$ & 1 \\
Rata-rata & $19,5 \%$ & 0,805 \\
\hline
\end{tabular}

Dari hasil penilaian didapatkan bahwa untuk persyaratan sumber daya, kesenjangan masih cukup besar. Secara alat uji laboratorium ini mendukung akan tetapi masih perlu diperbaki lagi secara dokumentasi dan prosedur-prosedur yang perlu dilengkapi dan dilakukan secara rutin.

Untuk persyaratan personil sebenarnya memiliki kesiapan karena memiliki kompetensi yang baik sesuai dengan lingkup. Namun, belum ada mekanisme evaluasi dari kompetensi dari personel yang melakukan pengujian. Sumber daya manusia/personil yang berkompeten apabila memiliki tiga kriteria yaitu tingkat kompetensi, kecakapan dan kebutuhan spesifik terhadap standar kompeten (De Coi).

\section{Persyaratan proses}

Persyaratan proses berisi persyaratan proses yang dilakukan pada laboratorium pengujian. Dari hasil assessment didapat berikut:

Tabel 5. Tingkat Kesiapan Persyaratan Proses

\begin{tabular}{|c|c|c|}
\hline \multirow{2}{*}{$\begin{array}{c}\text { Klausul } 7 \\
\text { Persyaratan } \\
\text { proses } \\
\end{array}$} & \multicolumn{2}{|c|}{ ISO/IEC 17025:2017 } \\
\hline & $\begin{array}{c}\text { Tingkat } \\
\text { Kesiapan }\end{array}$ & GAP \\
\hline $\begin{array}{l}\text { Kaji ulang } \\
\text { permintaan } \\
\text { tender dan } \\
\text { kontrak }\end{array}$ & $0 \%$ & 1 \\
\hline $\begin{array}{l}\text { Pemilihan, } \\
\text { verifikasi, dan } \\
\text { Validasi Metode }\end{array}$ & $35.5 \%$ & 0.645 \\
\hline Sampling & $75 \%$ & 0.25 \\
\hline $\begin{array}{l}\text { Penanganan } \\
\text { barang atau } \\
\text { bahan uji }\end{array}$ & $25 \%$ & 0.75 \\
\hline $\begin{array}{l}\text { Rekaman } \\
\text { Teknis }\end{array}$ & $0 \%$ & 1 \\
\hline $\begin{array}{l}\text { Evaluasi } \\
\text { Ketidakpastian } \\
\text { Pengukuran }\end{array}$ & $0 \%$ & 1 \\
\hline $\begin{array}{l}\text { Penjaminan } \\
\text { Keabsahan } \\
\text { Hasil }\end{array}$ & $0 \%$ & 1 \\
\hline Pelaporan Hasil & $0 \%$ & 1 \\
\hline Keluhan & $0 \%$ & 1 \\
\hline
\end{tabular}

\begin{tabular}{|c|c|c|}
\hline \multirow{2}{*}{$\begin{array}{c}\text { Klausul } 7 \\
\text { Persyaratan } \\
\text { proses }\end{array}$} & \multicolumn{2}{|c|}{ ISO/IEC 17025:2017 } \\
\hline & $\begin{array}{c}\text { Tingkat } \\
\text { Kesiapan }\end{array}$ & GAP \\
\hline $\begin{array}{l}\text { Pekerjaan yang } \\
\text { Tidak Sesuai }\end{array}$ & $0 \%$ & 1 \\
\hline $\begin{array}{l}\text { Pengendalian } \\
\text { Data dan } \\
\text { Manajemen } \\
\text { Informasi }\end{array}$ & $0 \%$ & 1 \\
\hline Rata-rata & $12,3 \%$ & 0,877 \\
\hline
\end{tabular}

Dalam persyaratan proses ini merupakan persyaratan yang paling rendah tingkat kesiapannya dibanding dengan persyaratan yang lain. Hal ini disebabkan proses yang dilakukan dalam laboratorium baru melayani pengujian dari litbangyasa dari pusat teknologi satelit LAPAN saja. Untuk permohonan pelayanan diluar dari kebutuhan litbangyasa pusat teknologi satelit LAPAN masih sangat sedikit. Selain itu proses evaluasi terhadap hasil pengujian juga belum dilakukan dan pengelolaan hasil data serta rekaman teknis masih belum didokumentasikan secara terstruktur.

\section{Persyaratan sistem manajemen}

Dalam persyaratan sistem manajemen terdapat 2 opsi pernyataan yaitu opsi $A$ dan opsi B. Jika memilih Opsi A maka terdapat dokumentasi sistem manajemen umum, dengan persyarataan:
a. Dokumentasi sistem manajemen umum
b. Pengendalian Dokumen
c. Pengendalian Rekaman
d. Tindakan terhadap Resiko dan Kesempatan
e. Peningkatan
f. Tindakan Korektif
g. Audit Internal
h. Tinjauan Manajemen

Tabel 6. Tingkat Kesiapan Persyaratan Sistem Manajemen

\begin{tabular}{lcc}
\hline $\begin{array}{c}\text { Klausul } 8 \\
\text { Persyaratan } \\
\begin{array}{c}\text { Sistem } \\
\text { Manajemen }\end{array}\end{array}$ & $\begin{array}{c}\text { ISO/IEC 17025:2017 } \\
\text { Tingkat } \\
\text { Kesiapan }\end{array}$ & GAP \\
\hline $\begin{array}{l}\text { Dokumentasi } \\
\text { sistem } \\
\text { manajemen }\end{array}$ & $0 \%$ & 1 \\
umum & & \\
$\begin{array}{l}\text { Pengendalian } \\
\text { Dokumen } \\
\text { Pengendalian }\end{array}$ & $50 \%$ & 0,5 \\
$\begin{array}{l}\text { Rekaman } \\
\text { Tindakan } \\
\text { terhadap Resiko }\end{array}$ & $50 \%$ & 0,5 \\
\end{tabular}


Kajian Kesiapan Laboratorium Pusat Teknologi Satelit LAPAN sebagai Laboratorium Pengujian terhadap Produk

\begin{tabular}{lcc}
\hline \hline dan & & \\
Kesempatan & & \\
Peningkatan & $0 \%$ & 1 \\
Tindakan & $25 \%$ & 0,75 \\
Korektif & $25 \%$ & 0,75 \\
Audit Internal & $0 \%$ & 1 \\
Tinjauan & $25 \%$ & 0,75 \\
Manajemen & & \\
Rata-rata & & \\
\hline
\end{tabular}

Untuk laboratorium pengujian pusat teknologi satelit ini mengarah pada persyaratan sistem manajemen Opsi A. Untuk Opsi A maka dalam penyusunan sistem dokumentasi dapat berdasarkan manajemen mutu ISO 9001. Jika tidak maka dalam penyusunan dokumentasi sesuai dengan ruang lingkup dari laboratorium tersebut. Dari hasil assessment yang dilakukan terhadap laboratorium pusat teknologi satelit, masih terdapat gap yang sangat besar untuk sebagian besar persyaratan manajemen. Hal ini dikarenakan masih dalam tahap perencanaan.

Selain itu laboratorium pusat teknologi satelit ini secara struk organisasi masih masuk dalam organisasi kerekayasaan yang ada pada pusat tersebut. Hal ini tidak memenuhi persyratan ISO/IEC 17025:2017. Laboratorium harus terdapat organisasi tersendiri agar terdapat kejelasan pertanggungjawaban dan manajemen.

\section{Rekomendasi Pemenuhan Persyaratan ISO/IEC 17025:2017}

Hasil analisis kesenjangan menunjukan laboratorium pusat teknologi satelit masih sangat besar kesenjangan terhadap persyaratan ISO/IEC 17025:2017. Tingkat kesiapan dari laboratorium tersebut sebesar $18 \%$ dari semua klausul persyaratan. Untuk pemenuhan persyaratan maka perlu langkah langkah dan urutan dalam menggulangi kesenjangan tersebut. Salah satu caranya dengan dilkukan diskusi atau focus group discussion) antar personel maupun manajemen laboratorium (Zamrudi 2014). Dari hasil diskusi tersebut dapat dihasilkan kebijakan dalam pengelolaan laboratorium. Selain itu untuk pemenuhan persyaratan seperti persyaratan teknis berdasarkan penelitian Cebekhu dan Mugova (2017) yaitu dengan menjaga kondisi fasilitas dan peralatannya. Adapun rekomendasi yang dapat diberikan dengan mempertimbangkan hasil penilaian dan analisis kesenjangan (gap analysis) yang di laboratorium pusat teknologi satelit untuk pemenuhan persyaratan ISO/IEC 17025:2017 adalah sebagai berikut:

\section{Untuk persyaratan umum}

Dalam pemenuhan persyaratan umum perlu dilakukan kebijakan dan atau prosedur terkait untuk mempertimbangkan analisis dan tindak lanjut resiko ketidakberpihakan. Laboratorium juga mulai melaksanakan dan memdokumentasi semua kegiatan yang dapat menghilangkan atau meminimalkan resiko ketidakberpihakan. Selain itu perlu evaluasi yang berkala komitmen untuk tidak memihak. Untuk aspek kerahasiaan, perlu adanya standar prosedur yang dibuat untuk mengatur penjaminan kerahasiaan. Selain itu pengaturan tentang penjaminan kerahasiann informasi atas data yang dihasilkan atau yang diperoleh saat pelaksanaan kegiatannya. Komitmen personel atas kerahasian juga perlu dibuat dalam bentuk komitmen yang mengikat secara hukum (Zapata,2007).

\section{Untuk persyaratan struktur}

Pemenuhan persyaratan struktur pada laboratorium pusat teknologi satelit ini lebih ditekankan pada legalitas hukum dan kejelasan tanggung jawab personel atau menjemen. Untuk legalitas hukum, perlu memastikan bahwa organisasi dan tata kerjanya mencakup tugas dan fungsi terkait layanan pengujian atau kalibrasi; apabila layanan tersebut merupakan pendapatan negara bukan pajak (PNBP) dengan ketentuan berlaku. Selain itu perlu dijelaskan kembali tugas dan fungsi masing masing dari personel maupun manajemen sesuai dengan struktur organisasi bertanggungjawab terhadap implementasi sistem manajemen.

\section{Untuk persyaratan sumber daya}

Secara proses persyaratan sumber daya perlu adanya prosedur yang perlu dilakukan secara jelas, Contohnya seperti ketertelusuran pengukuran dan rekaman hasil maupun kalibrasi. Selain itu perlu juga mereview pada prosedur terkait manajemen peralatan untuk memastikan bahwa telah menetapkan batas keberterimaan, verifikasi untuk memastikan pemenuhan batas keberterimaan dengan memperhitungkan akuasi dan/ ketidakpastiannya, serta melakukan validasi untuk memastikan pemenuhan persyaratan proses pengujian dan/atau kalibrasi di dalam ruang lingkupnya.

\section{Untuk persyaratan proses}

Untuk persyaratan proses cukup banyak yang dilakukan untuk pemenuhan persyaratan. Hal ini dikarenakan proses pelayanan masih untuk kebutuhan internal. Untuk pemenuhan persyaratan perlu penyesuaian dan prosedur yang ditetapkan. Seperti persyaratan bahwa bila 
pelanggan meminta laporan hasil uji dan kalibrasi yang berisi pernyataan kesesuain dengan spesifikasi, maka "decision rule" sebagaimana didefinisikan dalam standar ini diinformasikan kepada pelanggan (Elfriede,2018). Prosedur dan format laporan untuk memastikan memuat seluruh informasi yang diperoleh dari proses yang sepenuhnya memenuhi persyaratan harus ditetapkan. Selain itu perlu juga secara rutin untuk memastikan keabsahan hasil dan mereview prosedur secara berkala.

\section{Untuk persyaratan sistem manajemen}

Pemenuhan persyaratan sistem manajemen dengan opsi A untuk melakukan review untuk memastikan kembali bahwa seluruh rangkaian kegiatan audit internal, mulai dari penetapan program sampai dengan tindak lanjut hasil audit internal telah dilakukan sesuai dengan persyaratan standar (Shepherd,2019). Selain itu juga perlu melakukan kaji ulang terhadap manajemen dan prosedur yang disyaratkan oleh standar telah tercakup.

\section{KESIMPULAN}

Laboratorium pengujian yang dapat menguji produk satelit masih memiliki kesenjangan dalam pemenuhan persyaratan ISO/IEC 17025:2017. Data kuantitatif hasil penilaian menunjukan bahwa laboratorium pusat teknologi satelit LAPAN tingkat kesiapannya hanya sebesar $18 \%$. Laboratorium masih terkendala oleh legalitas hukum dan struktur organisasi yang belum sesuai dengan persyaratan ISO/IEC 17025:2017. Selain itu prosedur-prosedur seperti proses pelayanan, pelaporan hasil/rekaman dan kalibrasi alat ukur belum banyak ditetapkan.

Rekomendasi dalam pemenuhan kesenjangan persyaratan ISO/IEC 17025:2017 dapat menjadi acuan sehingga proses dalam akreditasi menjadi laboratorium pengujian khusus produk satelit khususnya dapat cepat berjalan.

\section{UCAPAN TERIMA KASIH}

Penulis mengucapkan terima kasih kepada Manajemen Puncak LAPAN, Pusispan LAPAN, TUV Reinland dan pihak-pihak yang telah mendukung penelitian ini.

\section{DAFTAR PUSTAKA}

Admaja, A. F. S. (2013). Studi Kesiapan Direktorat Standardisasi Dalam
Menerapkan SNI ISO/IEC 17065. Buletin

Pos dan Telekomunikasi, 11(3), 223-234.

Badan Standardisasi Nasional, (2018), Peraturan BSN Nomor 3 Tahun 2018 tentang Pedoman Pengembangan Standar Nasional Indonesia

Brocks, H., Hemmmje, M. et al. (2010), The PARSE. Insight GAP Analysis. Fern Universitat in Hagen.

Elfriede, D. P., Kusumaningrum, H. D., \& Lioe, H. N. (2018). Kajian Persyaratan Teknis Laboratorium Pengujian Di Industri Susu Terhadap Produk Infant Formula Sesuai ISO 17025: 2017, 219-230.

De Coi, J. L., Herder, E., Koeseling,.A et al. (n.d). A Model for Competence GAP Analysis. Germany: L3S Reserch Center and University of Hanonover.

Domain, P. (n.d.). 6U CubeSat Design Specification Rev. PROVISIONAL, 0-26.

International Standard Organization, (2011), Space Systems - Space debris mitigation requirements.

International Standard Organization, (2017), General Requirements for The Competence of Testing and Calibaration Laboratories.

International Standard Organization, (2017), Space Systems - Cube Satellites (CubeSats).

International Telecomunnication Union, (2016), Radio Regulation 2016 Rev WRC-15, http://handle.itu.int/11.1002/pub/80da2b36 -en

Jakhu, R, (n.d) Regulation of Small \& Micro Satellites, McGill University, Kanada.

Planet System Corporation, (2018), Payload Specification For $3 \mathrm{U}, 6 \mathrm{U}$ and $12 \mathrm{U}$. www.planetarysys.com

Perserikatan Bangsa-Bangsa, (2007), Space Debris Mitigation Guidelines of the Committee on the Peaceful Uses of Outer Space.

Perserikatan Bangsa-Bangsa, (1967), Treaty on Principles Governing the Activity of States in the Exploration and Use of Outer Space, include the Moon and Other Celestial Bodies (Outer Space Treaty).

Komite Akreditasi Nasional, (2017), Pedoman Gap Analisis ISO/IEC 17025:2017.

Lembaga Penerbangan dan Antariksa Nasional, 2017, Peraturan Kepala Lembaga Penerbangan dan Antariksa Nasional Nomor 10 Tahun 2017 Yang Mengatur Tentang Pelaksanaan Standardisasi 
Kajian Kesiapan Laboratorium Pusat Teknologi Satelit LAPAN sebagai Laboratorium Pengujian terhadap Produk Satelit Kubus (Cubeset) sesuai Dengan ISO 17025:2017 Hogan Eighfansyah Susilo dan lqbal Vernando

Penerbangan dan Antariksa, LAPAN, Jakarta.

Mansuette, B., \& Cebekhulu, B. (2017). Quality Control in a University Laboratory: Evaluating the Gap between ISO / IEC17025 Requirements and the Thin Section Laboratory's Processes., 614-625.

Pemerintah Indonesia, (2013), Undang-Undang Nomor 21 Tahun 2013 Yang Mengatur Tentang Keantariksaan. Lembaran Negara RI Tahun 2013 Nomor 133. Sekretariat Negara.Jakarta.

Pemerintah Indonesia, (2014), Undang-Undang Nomor 20 Tahun 2014 Yang Mengatur Tentang Standardisasi dan Penilaian Kesesuaian. Lembaran Negara RI Tahun 2014 Nomor 216. Sekretariat Negara.Jakarta.

Pemerintah Indonesia, (2018), Peraturan Pemerintah Nomor 38 Tahun 2018 Yang Mengatur Tentang Sistem Standardisasi dan Penilaian Kesesuaian Nasional. Lembaran Negara RI Tahun 2018 Nomor 110. Sekretariat Negara.Jakarta.

Shepherd, Christena, (2019), A System Engineering Approach to Quality Assurance for Aerospace Testing.

Zamrudi J. Kusumaningrum HD, Nuraida L. (2014). Analisis Pemenuhan persyaratan Food Safety System Certifiction 22000 di Industri Kemasan Pangan. Jurnal Mutu Pangan. 1(2): 46-53.

Zapata DG, Laurado M, Rauret G. (2007). Experience of Implementation ISO 17025 For The Accreditation of A University Testing Laboratory. Accreditation and Quality Assurance. 15: 681-689 
